\title{
Serotonin Receptor 2C -759C/T Polymorphism and Weight Change or Treatment Response to Mirtazapine in Korean Depressive Patients
}

\author{
Chi-Un Pae ${ }^{1,2} \bowtie$ \\ 1Department of Psychiatry, Bucheon St. Mary's Hospital, The Catholic University of Korea College of Medicine, Bucheon, Republic of Korea \\ ${ }^{2}$ Department of Psychiatry and Behavioral Sciences, Duke University Medical Center, Durham, NC, USA
}

Dear Sir.

I have read with great interest the paper by Dr. Lee and colleagues that investigated whether or not the serotonin receptor gene polymorphism (5-HT2C -759C/T) may be associated with a response to mirtazapine or mirtazapine-induced weight gain in patients with major depressive disorder (MDD) in Korean population. ${ }^{1}$ They reported that weight change and treatment response after mirtazapine administration was not significantly different among the three 5-HT 2C - 759 C/T genotypes. The authors concluded that the 5-HT $2 \mathrm{C}$ receptor $-759 \mathrm{C} /$ $\mathrm{T}$ polymorphism may not be associated with treatment response and weight change after 8 weeks of mirtazapine treatment.

To my knowledge, their study is the first one directly investigating the association of $5-\mathrm{HT} 2 \mathrm{C}-759 \mathrm{C} / \mathrm{T}$ with treatment response and weigh change to mirtazapine in Asian patients with MDD, although it failed to demonstrate any valuable pharmacogenetic findings. Hence various comments and standpoint from other researcher will add up more information for future studies.

The acceptable scientific backgrounds for their study may come from several viewpoints: firstly, the 5-HT $2 \mathrm{C}$ receptor has different transcriptional activity according to the 5-HT2C -759C/T polymorphism (rs3813929)'; secondly, Abnormalities of the 5-HT2C receptor activity have been suggested to be involved in susceptibility and treatment response in MDD. ${ }^{3}$ Despite the clear role of 5-HT2C receptor in antidepressant ef-

Received: July 2, 2013 Revised: August 2, 2013

Accepted: August 2, 2013 Available online: July 21, 2014

$\triangle$ Correspondence: Chi-Un Pae, MD, PhD

Department of Psychiatry, Bucheon St. Mary's Hospital, The Catholic University of Korea College of Medicine, 327 Sosa-ro, Wonmi-gu, Bucheon 420-717, Republic of Korea

Tel: +82-32-340-2140, Fax: +82-32-340-2255, E-mail: pae@catholic.ac.kr

(a) This is an Open Access article distributed under the terms of the Creative Commons Attribution Non-Commercial License (http://creativecommons.org/licenses/bync/3.0) which permits unrestricted non-commercial use, distribution, and reproduction in any medium, provided the original work is properly cited. fects has not been fully explained, the 5-HT2C receptor has been found to be directly implicated in the action mechanism of numerous antidepressants. ${ }^{3}$ In addition, paroxetine treatment has been proposed to be implicated in functional desensitization of the 5-HT2C receptors.; thirdly, a number of studies have suggested potential association of $-759 \mathrm{C} / \mathrm{T}$ polymorphism with the susceptibility to weight gain after various psychotropic agents, ${ }^{4}$ although currently available data still indicates that the exact role of it with weight gain should be more explored in a larger studies. ${ }^{5,6}$ Finally, mirtazapine is a noradrenergic and specific serotonergic antidepressant (NaSSA). The enhancement of serotonergic neurotransmission of mirtazpine is specifically mediated by stimulation of 5-HT1 receptors, while mirtazapine antagonizes postsynaptic 5-HT2 receptor. ${ }^{7}$ Regarding direct antagonistic activity of mirtazapine on 5-HT2 receptor, it may result in a stimulation of dopaminergic and adrenergic pathways, implementing antidepressant action in behavioral paradigms as well as favoring sleep and sexual function. ${ }^{8}$

Despite aforementioned backgrounds, Dr Lee and colleagues failed to find any association of the $-759 \mathrm{C} / \mathrm{T}$ polymorphism and treatment response/weight change after treatment with mirtazapine, we have to look inside of their study to improve our future researches. The most important issue of the study is an absolute small number of sample included in the study. According to the study results, they continuously present confusing results by a gender without any consistency in results format. However, when we only consider 243 female patients for sample size calculation on treatment response by 3 genotypes, In addition, a set of $\mathrm{p} \leq 0.05$ as statistical significance was not properly set since they have tried to test a numerous clinical variables and hypothesis, all p-values should be at least set at approximately 0.0035 level (baseline parameters, responder analysis, HAMD time variation, HAMD sub- 
group analysis and weight changes). Assuming these parameters, the sample power set at $80 \%$ and $\mathrm{p} \leq 0.01$ level should be at least 354 for female patients when looking at those carrying the CC genotype as compared with those carrying the CT genotype in HAMD difference (given that difference=2.25 and standard deviation=5). Hence the sample size was definitely insufficient for the study. In particular, the TT genotype carriers were only 4 in female $(C C=183$ and $C T=56)$, clearly indicating a deviation of genotype pooling that is very likely to give negative results on such primary endpoints. Regarding weight changes, the authors may have better chance to have positive results if they have reanalyzed the data $\mathrm{T}$ or $\mathrm{C}$ carriers (especially criteria of $>7 \%$ weight gain) rather than each genotype considering absolute less number of TT genotype. Some positive results by such grouping analysis were in fact demonstrated in other similar studies. For example, in another Korean data, $\mathrm{T}$ carriers were found to be less likely to have substantial weight gain $(>5 \%)$ and such association was supported by the repeated measures analysis even after controlling for possible confounding effects, although the whole sample size was only 84 (female $=39){ }^{9}$

Finally 5-HT2C -759C/T is likely in linkage disequilibrium with other functionally relevant variants that are more directly implicated in the pathogenesis of MDD. Future studies including re-sequencing of 5-HT2C -759C/T or epistatic interaction of 5-HT2C -759C/T with adjacent functional polymorphisms are warranted to identify such variants and to determine how they may contribute to the therapeutic and side effect mechanism of antidepressant.

\section{Acknowledgments}

This study was supported by a grant from the Korean Health Technology R\&D Project, Ministry of Health \& Welfare, Republic of Korea (HI12C0003).

\section{REFERENCES}

1. Lee HY, Oh CK, Ham BJ, Chang HS, Paik JW, Won ES, et al. No association between serotonin receptor $2 \mathrm{C}-759 \mathrm{C} / \mathrm{T}$ polymorphism and weight change or treatment response to mirtazapine in Korean depressive patients. Psychiatry Investig 2013;10:190-195.

2. Buckland PR, Hoogendoorn B, Guy CA, Smith SK, Coleman SL, O'Donovan MC. Low gene expression conferred by association of an allele of the 5-HT2C receptor gene with antipsychotic-induced weight gain. Am J Psychiatry 2005;162:613-615.

3. Pae CU, Forbes A, Patkar AA. Aripiprazole as adjunctive therapy for patients with major depressive disorder: overview and implications of clinical trial data. CNS Drugs 2011;25:109-127.

4. Godlewska BR, Olajossy-Hilkesberger L, Ciwoniuk M, Olajossy M, Marmurowska-Michałowska H, Limon J, et al. Olanzapine-induced weight gain is associated with the $-759 \mathrm{C} / \mathrm{T}$ and $-697 \mathrm{G} / \mathrm{C}$ polymorphisms of the HTR2C gene. Pharmacogenomics J 2009;9:234-241.

5. Vimaleswaran KS, Zhao JH, Wainwright NW, Surtees PG, Wareham NJ, Loos RJ. Association between serotonin 5-HT-2C receptor gene (HTR2C) polymorphisms and obesity- and mental health-related phenotypes in a large population-based cohort. Int J Obes 2010;34:10281033.

6. Park YM, Cho JH, Kang SG, Choi JE, Lee SH, Kim L, et al. Lack of association between the $-759 \mathrm{C} / \mathrm{T}$ polymorphism of the $5-\mathrm{HT} 2 \mathrm{C}$ receptor gene and olanzapine-induced weight gain among Korean schizophrenic patients. J Clin Pharm Ther 2008;33:55-60.

7. Blier P. Pharmacology of rapid-onset antidepressant treatment strategies. J Clim Psychiatry 2001;62(Suppl 15):12-17.

8. Millan MJ. Serotonin 5-HT2C receptors as a target for the treatment of depressive and anxious states: focus on novel therapeutic strategies. Therapie 2005;60:441-460.

9. Ryu S, Cho EY, Park T, Oh S, Jang WS, Kim SK, et al. -759 C/T polymorphism of 5-HT2C receptor gene and early phase weight gain associated with antipsychotic drug treatment. Prog Neuropsychopharmacol Biol Psychiatry 2007;31:673-677. 